Jurnal Ilmu Dan Teknologi Kesehatan

Vol 8, No 2, March 2021,

ISSN: 2338-9095 (Print)

ISSN: 2338-9109 (online)

\title{
Preventive Behaviors Related to Covid-19 Among High School Students: Cross-Sectional Web-Based Survey
}

\author{
Fika Muntahaya, Thoriq Fajar Batuah, Hoirun Nisa* \\ State Islamic University Syarif Hidayatullah Jakarta, Indonesia \\ *Email: hoirun.nisa@uinjkt.ac.id
}

\author{
Article history \\ Posted, Dec 26th, 2020 \\ Reviewed, Jan 20th, 2021 \\ Received, March 5th, 2021
}

\begin{abstract}
The increase in COVID-19 cases encourages the need for health efforts from various sectors. The number of COVID-19 confirmed cases in Palangka Raya City is the highest in Central Kalimantan province. The Ministry of Education urged the implementation of $3 M$ education, such as wearing masks, washing hands, and social distancing, to stop the transmission of COVID-19. This study aims to describe the level of knowledge, attitudes, and preventive behaviors related to COVID-19 and the association between knowledge and attitudes with preventive behaviors related to COVID-19 in students of MAN Kota Palangka Raya. This research is a cross-sectional study that involved 339 students as respondents. Data was collected using google form in October 2020. $98.8 \%$ of students had good knowledge of COVID-19, and $87.0 \%$ of students had positive attitudes about preventing COVID-19, but only $54.6 \%$ of students had good preventing behaviors related to COVID-19. Association was found between attitudes toward COVID-19 with preventive behaviors related to COVID-19 in MAN Palangka Raya City students in 2020. 3M's preventive behavior education efforts still need to be improved to stop the transmission of COVID-19.
\end{abstract}

Keywords: attitudes; COVID-19; knowledge; preventive behavior

\begin{abstract}
ABSTRAK
Peningkatan kasus COVID-19 mendorong perlunya upaya kesehatan dari berbagai sektor. Angka kasus terkonfirmasi COVID-19 di Kota Palangka Raya menduduki posisi tertinggi seprovinsi Kalimatan Tengah. Kementerian Pendidikan menghimbau pelaksanaan edukasi 3M, yaitu memakai masker, mencuci tangan, dan menjaga jarak, dalam rangka memutus penularan COVID-19. Penelitian ini bertujuan menggambarkan tingkat pengetahuan, sikap dan perilaku mengenai pencegahan COVID-19 serta hubungan antara pengetahuan dan sikap dengan perilaku pencegahan COVID-19 pada Siswa MAN Kota Palangka Raya Tahun 2020. Penelitian ini menggunakan desain studi cross sectional dengan jumlah responden sebesar 339 siswa. Data dikumpulkan melalui google form pada bulan Oktober 2020. Sebesar 98,8\% siswa memiliki pengetahuan COVID-19 yang baik dan 87,0\% siswa memiliki sikap positif mengenai pencegahan COVID-19, namun hanya 54,6\% siswa yang memiliki perilaku pencegahan COVID-19 yang baik. Terdapat hubungan antara sikap dengan perilaku
\end{abstract}


pencegahan COVID 19 pada siswa MAN Kota Palangka Raya tahun 2020. Upaya edukasi perilaku pencegahan $3 \mathrm{M}$ masih perlu ditingkatkan dalam upaya memutus penularan COVID19.

Kata Kunci: pengetahuan; COVID-19; sikap; perilaku pencegahan

\section{INTRODUCTION}

Coronavirus $(\mathrm{CoV})$ is part of the virus family that causes illnesses from flu to severe illnesses such as Middle East Respiratory Syndrome (MERS-CoV) and Severe Acute Respiratory Syndrome (SARS-CoV). The disease caused by the coronavirus or known as COVID-19, is a new type discovered in 2019 and has not been known to attack humans before (Mona, 2020; World Health Organization, 2020; Sari et al., 2020). COVID-19 attacks humans regardless of age or gender. Common symptoms of COVID-19 infection include acute respiratory problems such as fever, cough, and shortness of breath. This virus's incubation period has an average of 5-6 days, with the longest 14 days. The disease can cause pneumonia, acute respiratory syndrome, kidney failure, and death (Kemenkes RI, 2020a). COVID-19 is spread from one person to another through close contact and droplets.

COVID-19 cases have infected 215 countries, including Indonesia. The COVID-19 cases worldwide on September
21, 2020, had reached 30,675,675 confirmed cases and 954,417 cases that led to death. COVID-19 cases in Indonesia have spread across 494 districts or cities, with a total of 248,852 confirmed cases and 9,677 cases that have resulted in death as of August 21, 2020 (Kemenkes RI, 2020). A risk-zone map presented by the COVID-19 Task Force (Satuan Tugas Penanganan COVID-19, 2020) official website shows that Palangka Raya City is in a high-risk zone in Central Kalimantan Province, while the surrounding areas of the city are currently in a moderate riskzone. Moreover, Palangka Raya City has the highest number of COVID-19 confirmed cases in the province of Central Kalimantan (Pemerintah Provinsi Kalimantan Tengah, 2020).

Based on the Guidelines for the Prevention and Control of Corona Virus Disease (COVID-19), the preventive behavior against the COVID-19 among individuals includes washing hands using soap and running water or alcohol-based antiseptic liquid, wearing a mask, and keeping a minimum distance of 1 meter. 
Other behaviors to prevent COVID-19 are limiting interaction with other people, immediately cleaning themselves after traveling, increasing clean and healthy behavior (PHBS), managing comorbidities, managing mental and psychosocial health, applying cough and sneeze ethics, and adapting to new habits (Kemenkes RI, 2020a). The Indonesian Ministry of Education and Culture has also issued a letter of appeal for the implementation of $3 \mathrm{M}$ education, namely wearing masks, washing hands, and maintaining distance, in teaching and learning activities (Kemendikbud RI, 2020). The behavior of $3 \mathrm{M}$ is now heavily campaigned to prevent the transmission of COVID-19 in the community.

The theory of "Precede-Proceed" developed by Lawrence Green in 1991 explains that a person's health behavior is influenced by predisposing factors, enabling factors, and reinforcing factors (Irwan, 2017). Predisposing factors that influence health behavior include knowledge, attitudes, beliefs, and other demographic factors. The enabling or supporting factors include the availability of facilities, resources, affordability. Meanwhile, reinforcing factors include support from family, friends, health workers, and others. Research conducted by Prihanti et al. (2018) shows a significant relationship between knowledge and behavior. A person with a good level of knowledge has a better chance to behave in a clean and healthy life than someone with a lower knowledge level. Also, Purnamasari and Raharyani's (2020) study on the Wonosobo community also shows a significant relationship between knowledge and community behavior related to COVID-19. The study results conducted by Rasyid R.R et al. (2019) in adolescents have reported a significant relationship between attitudes and prevention behavior for HIV / AIDS infection. Regarding the PSBB policy during the pandemic, the Wiranti et al. (2020) study shows a significant relationship between attitude and compliance with the PSBB policy. Lestari (2019) also found a strong relationship between attitude and handwashing behavior in her study.

This study focuses on predisposing factors related to health behavior, namely the knowledge and attitudes of high school students. Senior high school students are generally in the age range of 15 to 19 years, constituting the youth age group. Although not the most vulnerable to COVID-19, the teenage age group can potentially have an infection with very 
minimal symptoms. This potential causes the adolescent age group to be a source of transmission of COVID-19 without them knowing it. As a result, the spread of the corona virus will increase and spread rapidly. This study aims to determine the level of knowledge, attitudes, and preventive behaviors against COVID-19 in high school students. This study will also analyze the relationship between knowledge and attitudes with COVID-19 prevention behavior in high school students.

\section{METHOD}

This study was an analytic observational study with a cross-sectional design. This study's population was all students of Madrasah Aliyah Negeri Palangka Raya City, which had 976 students. This study's sample was selected through the stratified random sampling method with a sample size of 339 students. The data in this study were collected in October 2020 by an online questionnaire (google form). The questionnaire was made by researchers that have been tested for validity and reliability. This research was conducted based on research ethics and was approved by the Faculty of Health Sciences State Islamic University Syarif Hidayatullah Jakarta number
Un.01/F.10/KP.01.1/KE.SP/011.08.001/20

20. Informed consent was available on the first page of the online form and filled out by each respondent before answering the questionnaire.

Ten questions measured the students' knowledge, attitudes, and preventing behaviors related to COVID-19. The correct answer score of knowledge questions was given a score of 1 , and the wrong answer was given a score of 0 . The knowledge score was categorized as good if the total score attains more than $75 \%$ and was categorized as inferior if the total score merely attains $75 \%$ or less (Lestari, 2019). Simultaneously, the attitudes and preventing behaviors related to COVID-19 were measured using a modified Likert scale. The attitudes score was categorized as positive if the total score attains more than $75 \%$ and was categorized as negative if the total score merely attains $75 \%$ or less (Lestari, 2019). The preventing behaviors related to the COVID-19 score were categorized as good if the total score attains more than $75 \%$ and was categorized as inferior if the total score merely attains $75 \%$ or less (Lestari, 2019). Univariate analysis was performed using frequency distribution which is presented in tabular form. Then bivariate analysis was 
performed using the chi-square test and presented in tables and figures.

\section{RESULTS AND DISCUSSION}

A total of 339 high school students have participated in the study. Respondents' characteristics, knowledge regarding COVID-19, attitudes towards COVID-19, and preventive behaviors against COVID19 are presented in Table 1.

Table 1. Respondents' characteristics, knowledge, attitudes, and COVID-19 preventive behaviors

\begin{tabular}{|c|c|c|}
\hline Variable & $\mathbf{n}$ & $\%$ \\
\hline Age (years) & 339 & $15.9 \pm 0.9^{*}$ \\
\hline \multicolumn{3}{|l|}{ Gender } \\
\hline Female & 213 & 62.8 \\
\hline Male & 126 & 37.2 \\
\hline \multicolumn{3}{|l|}{ Grade } \\
\hline $\mathrm{X}$ & 119 & 35.1 \\
\hline XI & 111 & 32.7 \\
\hline XII & 109 & 32.2 \\
\hline \multicolumn{3}{|l|}{ Knowledge related to COVID-19 } \\
\hline Good $(>75 \%)$ & 335 & 98.8 \\
\hline Poor $(\leq 75 \%)$ & 4 & 1.2 \\
\hline \multicolumn{3}{|l|}{ Attitudes toward COVID-19 } \\
\hline Positive $(>75 \%)$ & 295 & 87.0 \\
\hline Negative $(\leq 75 \%)$ & 44 & 13.0 \\
\hline \multicolumn{3}{|c|}{ Preventive Behaviors related to COVID-19 } \\
\hline Good $(>75 \%)$ & 185 & 54.6 \\
\hline Poor $(\leq 75 \%)$ & 154 & 45.4 \\
\hline
\end{tabular}

${ }^{*}$ Values are mean \pm SD

Table 1 shows that respondents' mean of age was 15.9 years, and most were female. The results showed that among 339 students, $98.8 \%$ of them had good knowledge about the transmission and prevention of COVID-19. Also, most of the students had positive attitudes towards COVID-19 (87.0\%). Simultaneously, only $54.6 \%$ of students had good preventive behaviors related to COVID-19. The distribution of respondents' answers regarding questions on preventive behaviors related to COVID-19, knowledge related to COVID-19, and attitudes toward COVID-19 are presented in Table 2, Table 3, and Table 4, respectively. 
Table 2. Respondents' Preventive Behaviors against COVID-19

\section{Questions}

Do you wear a face mask when you go out?

Do you carry a spare face mask with you when you go out?

Do you change your face mask every 4 hours?

Do you take off your mask or put it on your chin when you speak?

Do you wash the mask immediately after using it?

Do you keep a distance from other people in public places (with a minimum distance of one meter)?

Do you avoid shaking hands or touching your friends?

Do you keep your distance when waiting in line at the shopping mall?

Do you always wash your hands with soap and running water after doing activities?

Do you always carry a Hand Sanitizer with you and use it when water and handwashing soap is not available?

\begin{tabular}{rrrrrr}
\multicolumn{2}{c}{ Always-often } & \multicolumn{2}{c}{ Sometimes } & \multicolumn{2}{r}{$\begin{array}{r}\text { Infrequently- } \\
\text { never }\end{array}$} \\
\hline $\mathbf{n}$ & $\mathbf{\%}$ & $\mathbf{n}$ & $\mathbf{\%}$ & $\mathbf{n}$ & $\mathbf{\%}$ \\
333 & 98.2 & 5 & 1.5 & 1 & 0.3 \\
109 & 32.2 & 114 & 33.0 & 118 & 34.8 \\
& & & & & \\
71 & 20.9 & 121 & 35.7 & 147 & 43.3 \\
79 & 16.8 & 116 & 34.2 & 144 & 42.5 \\
206 & 60.8 & 81 & 23.9 & 52 & 15.4 \\
238 & 70.2 & 82 & 24.2 & 19 & 5.6 \\
155 & 45.7 & 126 & 37.2 & 58 & 17.1 \\
304 & 89.6 & 26 & 7.7 & 9 & 2.7 \\
314 & 92.6 & 24 & 7.1 & 1 & 0.3 \\
207 & 61.0 & 78 & 23.0 & 54 & 15.9 \\
& & & & & \\
& & & & &
\end{tabular}

This study showed that only $54.5 \%$ of students had good preventive behaviors related to COVID-19, and the rest, precisely $45.5 \%$ of students, had poor COVID-19 prevention behavior.

However, Setyawati's study showed that most teenagers in Sidoarjo had implemented good preventive behaviors related to COVID-19 (93.8\%) (Setyawati et al., 2020). Other studies conducted on the general public also showed that most people had implemented good preventive behaviors related to COVID-19 (Moudy and Syakurah, 2020; Purnamasari and Raharyani, 2020). This contradictory result may occur due to differences in the variety of questions used to determine the implementation of preventive behaviors related to COVID-19. Furthermore, the low level of preventive behaviors related to COVID-19 among students in this study could be due to boredom due to a long-running pandemic, which is about seven months. When this study was conducted, students become ignorant towards COVID19preventive behaviors.

Most of the students of MAN Palangka Raya City have implemented the use of face masks when they go out (98.2\%), but only $32.2 \%$ of students who always or often carry a spare face mask when they go out and $20.9 \%$ of students who 
change their masks every 4 hours consecutively. Also, it was found that only $42.5 \%$ of students stated that they rarely or never opened or put their face masks on their chins when speaking, and $60.8 \%$ of students always or often washed their face masks immediately after they used them. The study conducted by Sari et al. also showed only $74.19 \%$ of the Ngronggah community obeyed the behavior of using face masks during the COVID-19 pandemic (Sari et al., 2020).

The wearing of a face mask is a practical, easy, and cheap NonPharmaceutical Intervention (NPI) to prevent transmission of COVID-19. Based on the study of Eikenberry et al. (2020), the wearing of face masks is beneficial to limit the transmission of COVID-19 and decrease the burden of the epidemic, especially when combined with other NPI. Correspondingly, Li et al. (2020) also mentioned in their study that the use of face masks accompanied by social distancing was effective in flattening the epidemic curve. Therefore, the wearing of face masks in the proper way must be considered to maximize the benefits of the face masks themselves. Based on the Guidelines for the Prevention and Control of Corona Virus Disease (COVID-19), face masks must cover the nose and mouth and must be changed every 4 hours and washed immediately after use (Kemenkes RI, 2020a).

Students who stated that they always keep a minimum distance of one meter from other people in public places and keep a distance when queuing at a shopping place were $70.2 \%$ and $89.6 \%$, respectively. Overall these findings are in line with findings reported by N. P. E. D. Yanti et al. (2020), which showed that $71.3 \%$ of Balinese people always maintain a minimum distance of 1 meter from other people, and by B. Yanti et al. (2020) which showed that $93 \%$ of the community has good behavior towards social distancing. As is well known, one of the COVID-19 transmissions is by droplets. Transmission by droplets can occur at a short distance, one meter (Kemenkes RI, 2020a). Hence, when dealing with respiratory symptoms such as coughing and sneezing at this distance, the risk of droplets hitting the mucosa (mouth and nose) or the conjunctiva (eyes) is higher.

The behavior of social distancing for most MAN Palangka Raya City students has shown promising results. However, only $45.7 \%$ of students stated that they 
always avoid shaking hands or touching their friends. This result demonstrated that adolescents have tolerance towards their friends. In line with that, according to Andrews et al. (2020), adolescence was often associated with increased risktaking, the need for social relations and peer acceptance, and sensitivity to peer influence. The instability of the social environment in this adolescent age group has resulted in high adolescent loneliness levels during the COVID-19 pandemic (Barreto et al., 2020; Sagita and Hermawan, 2020). Therefore, implementing a social distancing behavior with friends in youth groups will be quite challenging in this era of the COVID-19 pandemic.

The handwashing behaviors with soap and running water after doing activities have been implemented by almost all students in MAN Palangka Raya City $(92.6 \%)$. This result is similar to the study by N. P. E. D. Yanti et al. (2020) that showed $84 \%$ of Balinese people always wash their hands with soap or hand sanitizer after handling objects in public places. However, in this study, only $61.0 \%$ of students stated that they always carry hand sanitizers and use them when water and handwashing soap are not available. Based on the study conducted by Situmeang and Sembiring (2019), hand sanitizer is applicable as alternative handwashing. Nevertheless, only hand sanitizer with an alcohol content of $60-95 \%$ or more effectively kills germs. This idea follows the CDC's recommendation to use an alcohol-based hand sanitizer with a level of $60 \%$ when water and soap are not available (CDC, 2020). The high level of handwashing among students in this study was in line with the study of Głąbska et al. (2020) that explained the increase in handwashing behavior among adolescents in Poland during the COVID-19 pandemic compared to before the pandemic. Education regarding proper handwashing behavior needs to be carried out, not only to stop the transmission of COVID-19 but also to prevent the spread of other viruses and bacteria that can be transmitted from person to person. 
Table 3. Respondents' Knowledge Related to COVID-19

\begin{tabular}{lrr}
\hline \multicolumn{1}{c}{ Statements } & n & \% \\
\hline COVID-19 is a disease caused by a virus & 339 & 100,0 \\
$\begin{array}{l}\text { Droplets do not transmit COVID-19 } \\
\text { The average incubation period for COVID-19 is 14 days }\end{array}$ & 252 & 74,3 \\
$\begin{array}{l}\text { Contact with contaminated items is the main transmission medium for } \\
\text { COVID-19 }\end{array}$ & 314 & 98,5 \\
$\begin{array}{l}\text { A person who has been confirmed to have COVID-19 needs to be isolated } \\
\text { Good etiquette of cough/sneeze is to cover your mouth with your upper arm } \\
\text { or a tissue }\end{array}$ & 339 & 100,0 \\
$\begin{array}{l}\text { Increasing immunity with consumption of fruits and vegetables and exercise } \\
\text { is not necessary }\end{array}$ & 320 & 98,8 \\
$\begin{array}{l}\text { The use of hand sanitizers with 70\% alcohol content can be done at any time } \\
\text { to replace washing hands }\end{array}$ & 316 & 93,4 \\
$\begin{array}{l}\text { Wash your hands with soap and clean water to prevent transmission of } \\
\text { COVID-19 }\end{array}$ & 331 & 97,6 \\
$\begin{array}{l}\text { To avoid spreading COVID-19, keep a safe distance of at least 1 meter from } \\
\text { other people }\end{array}$ & 329 & 97,1
\end{tabular}

The results regarding the high level of knowledge related to COVID-19 in MAN Palangka Raya City students in this study are in line with the study of Setyawati et al., which showed that $91.5 \%$ of teenagers in Sidoarjo have good knowledge related to COVID-19 (Setyawati et al., 2020). However, these results were in contrast to the study conducted on other high school students. Natalia et al. (2020) at SMA PGRI Lembang shows a moderate level of knowledge related to COVID-19 (69,7\%). Suwandi and Malinti's (2020) study at Balikpapan Adventist High School showed that only $76.7 \%$ of students have good knowledge related to COVID-19. The dissimilarity of this result may be due to the difference in time in data collecting. Data collecting of Natalia et al. (2020) study was conducted in May 2020, and Suwandi and Malinti (2020) study done before September 2020, while the data collection in this study was conducted in October 2020 a pandemic COVID-19 have lasted less than eight months. Therefore, it is likely that students have been exposed to much information about COVID-19 from various sources. The students' knowledge related to agent, incubation period, transmission, and prevention of COVID19 was at a high level. This could be seen clearly from the proportion of students who can answer each question correctly, which attain 92,6-100\% (Table 2). 
However, only $74,3 \%$ of students whose knew that COVID-19 was transmitted by droplet. This probably happened because the students did not understand the term "droplet". Droplet is a term for particles with a diameter of $5 \mu \mathrm{m}$ that can be inhaled and remain in the upper respiratory tract and mucosa, produced through coughing, sneezing, and speaking (WHO, 2009). This study's result was contradictory to a previous study that showed that $96 \%$ of Indonesians already know that COVID-19 can be transmitted through coughing and sneezing (Moudy and Syakurah, 2020).

Table 4. Respondents' Attitudes Toward COVID-19

\begin{tabular}{|c|c|c|c|c|}
\hline \multirow{2}{*}{ Statements } & \multicolumn{2}{|c|}{ Agree } & \multicolumn{2}{|c|}{ Disagree } \\
\hline & $\mathbf{n}$ & $\%$ & $\mathbf{n}$ & $\%$ \\
\hline $\begin{array}{l}\text { Understanding of the transmission of COVID-19 is needed to prevent } \\
\text { the disease COVID-19 }\end{array}$ & 334 & 98.6 & 5 & 1.5 \\
\hline $\begin{array}{l}\text { In my opinion, it is not essential to know COVID-19 disease } \\
\text { information }\end{array}$ & 11 & 3.9 & 326 & 96.2 \\
\hline I realize that behavior can influence the transmission of COVID-19 & 247 & 72.9 & 92 & 27.1 \\
\hline $\begin{array}{l}\text { In my opinion, social distancing can stop the transmission of } \\
\text { COVID-19 }\end{array}$ & 313 & 92.3 & 26 & 7.7 \\
\hline Washing hands with soap can prevent transmission of COVID-19 & 332 & 97.9 & 7 & 2.1 \\
\hline mask is only for people who are sick & 36 & 10.6 & 303 & 89.4 \\
\hline When & 321 & 94.7 & 18 & 5.3 \\
\hline ng from close friends & 41 & 12.1 & 298 & 87.9 \\
\hline & 326 & 96.1 & 13 & 3.9 \\
\hline Temperature check before entering a public place is just wasting time & 30 & 8.8 & 309 & 91.1 \\
\hline
\end{tabular}

The majority of students showed positive answers to each statement regarding attitudes towards the prevention of COVID-19, which ranged from 92,3 $98,6 \%$. However, the results showed that awareness about behavior that could influence the transmission of COVID is lower among other attitudes (72,9\%). This awareness certainly affects students in implementing COVID-19 prevention behavior. Research related to attitudes about COVID-19 among high school students in Indonesia has not been found. However, other studies conducted on communities in Indonesia generally show the same results as this study. The study conducted in Sulawesi showed $97,8 \%$ of people have a positive attitude (Sembiring and Meo, 2020). The study conducted in East Java showed $85,5 \%$ of people have a positive attitude toward COVID-19 prevention (Suprayitno et al., 2020). 
Table 5. Associations of Knowledge and Attitudes with COVID-19 Preventive Behaviors

\begin{tabular}{|c|c|c|c|c|c|c|c|}
\hline \multirow{3}{*}{ Independent Variable } & \multicolumn{4}{|c|}{ Preventive Behaviors } & \multirow{3}{*}{ P-value } & \multirow{3}{*}{ OR } & \multirow{3}{*}{$95 \% \mathrm{CI}$} \\
\hline & \multicolumn{2}{|c|}{ Good } & \multicolumn{2}{|c|}{ Poor } & & & \\
\hline & $\mathbf{n}$ & $\%$ & $\mathrm{n}$ & $\%$ & & & \\
\hline \multicolumn{8}{|l|}{$\begin{array}{l}\text { Knowledge related to COVID- } \\
19\end{array}$} \\
\hline Good & 183 & 54.6 & 152 & 45.4 & \multirow{2}{*}{0.854} & \multirow{2}{*}{1.204} & \multirow{2}{*}{$0.168-8.648$} \\
\hline Poor & 2 & 50.0 & 2 & 50.0 & & & \\
\hline \multicolumn{8}{|l|}{$\begin{array}{l}\text { Attitudes towards COVID-19 } \\
\text { prevention }\end{array}$} \\
\hline Good & 171 & 58.0 & 124 & 42.0 & \multirow{2}{*}{0.002} & \multirow{2}{*}{2.955} & \multirow{2}{*}{$1.504-5.805$} \\
\hline Poor & 14 & 31.8 & 30 & 68.2 & & & \\
\hline
\end{tabular}

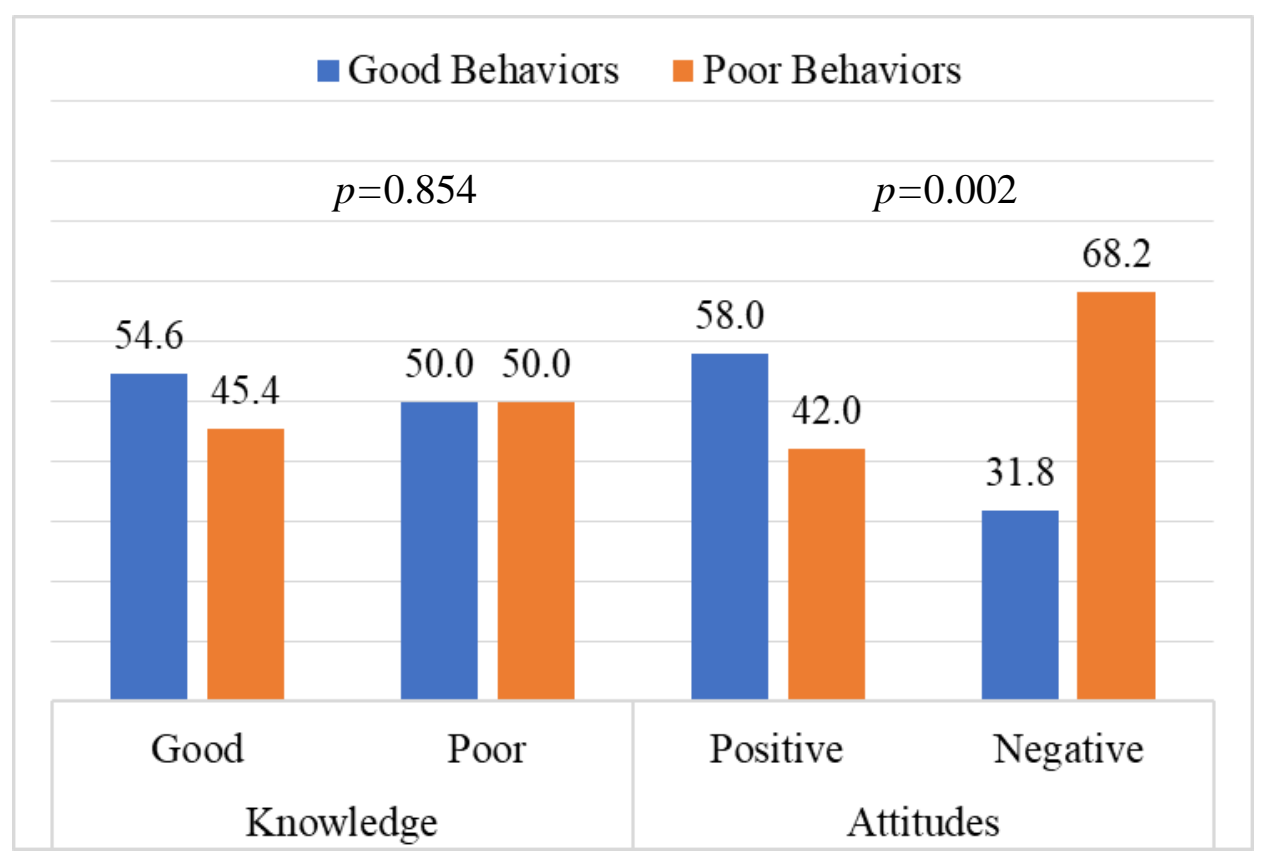

Figure 1. COVID-19 Preventive Behaviors with Students' Knowledge and Attitudes

Figure 1 shows $p$-value for the relationship between knowledge about COVID-19 and COVID-19 prevention behavior is more than 0.05 . It means there is no significant association between knowledge about COVID-19 and preventing behaviors related to COVID-19. However, the resulting $p$-value for the association between attitudes towards COVID-19 and preventing behaviors related to COVID-19 is less than 0.05 , which indicates a significant association between attitudes towards COVID-19 and COVID-19 prevention behavior. An OR value of $2.955(95 \%$ CI 1.504 - 5.805) was also obtained, which means students who have positive attitudes towards COVID-19 are 2.9 times more likely to have better- 
preventing behaviors related to COVID-19 than students who have negative attitudes towards COVID-19.

The insignificant association between knowledge about COVID-19 and preventing behavior related to COVID-19 in students of MAN Kota Palangka Raya in this study is different from the results of previous studies, which show that there is a significant relationship between knowledge about COVID-19 and preventing behavior related to COVID-19 (Moudy and Syakurah, 2020; Setyawati et al., 2020). The progress of the COVID-19 pandemic is the more often exposed to information media regarding COVID-19, so that knowledge about COVID-19 was improved. According to Irwan (2017), the dimensions of cognitive processes in the new taxonomy are memorizing, understanding, applying, analyzing, evaluating, and creating. MAN Palangka Raya City students' high knowledge regarding COVID-19 is only limited to the level of memorization and understanding. It can be seen from the results of this study, showing that almost all students have good knowledge of COVID-19, but some still have poor COVID-19 prevention behavior.
The significant association between attitudes towards COVID-19 and preventing behaviors related to COVID-19 in this study is in line with Moudy and Syakurah's (2020) study results. An attitude is a form of feeling reaction or a person's evaluation of an object, which results in a feeling of support or feelings of not supporting that object. Attitude is the readiness to react to an object in specific ways. Readiness is defined as a potential tendency to react in a certain way when an individual is faced with a stimulus that wants a response so that a positive attitude will tend to encourage someone to behave positively (Putri and Setianingsih, 2016).

\section{CONCLUSION}

MAN Palangka Raya City students already have good knowledge about COVID-19 and a positive attitude towards COVID-19 prevention. However, some students still have poor preventing behaviors related to COVID-19. Students' knowledge regarding droplets to transmit COVID-19 and awareness that behavior can affect the transmission of COVID-19 show unfavorable results. Changing masks every 4 hours when outside the home and social distancing behavior from friends of the students need to be improved. Besides, attitudes towards COVID-19 were found 
to be associated with the COVID-19 prevention behavior of students. Accordingly, even though students' knowledge and attitudes show promising results, educational efforts and other strategic approaches are still needed, especially in improving student attitudes towards COVID-19 to advance optimal COVID-19 prevention behavior.

This study has several limitations, such as using a cross-sectional study design that does not explain the observed variables' temporal relationship. Moreover, this study is only set to predisposing factors, so it cannot explain other factors related to COVID-19 prevention behavior in adolescents. Regarding this study's limitation, research related to other factors that influence COVID-19 prevention behavior in adolescents needs to be developed with better methods to produce other information. That has not been conveyed in this study, hoping that it will help plan a more advanced approach effective in enhancing 3M's COVID-19 prevention behavior.

\section{ACKNOWLEDGEMENT}

Researchers would like to thank all parties involved in this research, especially all teachers and staff of MAN Kota Palangka
Raya, for help and support and all students for participation in this study.

\section{REFERENCES}

Andrews, J.L., Foulkes, L., Blakemore, S.J. (2020). Peer Influence in Adolescence: Public-Health Implications for COVID-19. Trends in Cognitive Sciences, 24, 585-587. https://doi.org/10.1016/j.tics.2020.0 5.001

Barreto, M., Victor, C., Hammond, C., Eccles, A., Richins, M.T., Qualter, P. (2020). Loneliness around the world: Age, gender, and cultural differences in loneliness. Personality and Individual Differences, 169, 110066. https://doi.org/10.1016/j.paid.2020.1 10066

CDC. (2020). Show Me the Science When \& How to Use Hand Sanitizer in Community Settings | Handwashing | CDC [WWW Document]. URL https://www.cdc.gov/handwashing/s how-me-the-science-handsanitizer.html (accessed 3.2.21).

Eikenberry, S.E., Mancuso, M., Iboi, E., Phan, T., Eikenberry, K., Kuang, Y., Kostelich, E., Gumel, A.B. (2020). To mask or not to mask: Modeling the potential for face mask use by the general public to curtail the COVID-19 pandemic. Infectious Disease Modelling, 5, 293-308. https://doi.org/10.1016/j.idm.2020.0 4.001

Głąbska, D., Skolmowska, D., Guzek, D. (2020). Population-Based Study of the Influence of the COVID-19 Pandemic on Hand Hygiene Behaviors-Polish Adolescents' COVID-19 Experience (PLACE-19) 
Study. Sustainability, 12, 4930. https://doi.org/10.3390/su12124930

Irwan. (2017). Etika dan Perilaku Kesehatan. Yogyakarta: CV. Absolute Media.

Kemendikbud RI. (2020). Surat Edaran Pelaksanaan Edukasi 3M.

Kemenkes RI. (2020a). Pedoman Pencegahan dan Pengendalian Corona Virus Disease (Covid-19). Jakarta: Kementerian Kesehatan RI.

Kemenkes RI. (2020b). Info Corona Virus Archives " Info Infeksi Emerging Kementerian Kesehatan RI [WWW Document]. Info Infeksi Emerging Kementerian Kesehatan RI. URL https://covid19.kemkes.go.id/categor $\mathrm{y} /$ situasi-infeksi-emerging/infocorona-virus/ (accessed 9.21.20).

Lestari, A.O.A.W. (2019). Hubungan Pengetahuan Dan Sikap Terhadap Perilaku Cuci Tangan Pada Masyarakat Kelurahan Pegirian. JPK, $7, \quad 1$. https://doi.org/10.20473/jpk.V7.I1.2 019.1-11

Li, T., Liu, Y., Li, M., Qian, X., Dai, S.Y. (2020). Mask or no mask for COVID-19: A public health and market study. PLoS ONE, 15, e0237691. https://doi.org/10.1371/journal.pone. 0237691

Mona, N. (2020). Konsep Isolasi dalam Jaringan Sosial untuk Meminimalisasi Efek Contagious (Kasus Penyebaran Virus Corona di Indonesia). Jurnal Sosial Humaniora Terapan, 2.

Moudy, J., Syakurah, R.A. 2020. Pengetahuan terkait Usaha
Pencegahan Corona Virus Disease (COVID-19) di Indonesia. Higeia Journal of Public Health Research and Development 4, 333-346.

Natalia, R.N., Malinti, E., Elon, Y. (2020). Kesiapsiagaan Remaja dalam Menghadapi Wabah COVID-19. Jurnal Ilmiah Kesehatan Diagnosis, 15, 107-111.

Pemerintah Provinsi Kalimantan Tengah. (2020). Media Center Satuan Tugas Covid-19 Kalimantan Tengah [WWW Document]. URL https://corona.kalteng.go.id/ (accessed 9.21.20).

Prihanti, G.S., et al. (2018). Faktor-Faktor Yang Mempengaruhi Tingkat Perilaku Hidup Bersih Dan Sehat Pada Tatanan Rumah Tangga Di Wilayah Kerja Puskesmas Poned X. Santika Medika, 14(1). https://doi.org/10.22219/sm.Vol14.S MUMM1.6644

Purnamasari, I., Raharyani, A.E. (2020). Tingkat Pengetahuan dan Perilaku Masyarakat Kabupaten Wonosobo Tentang COVID-19. Jurnal Ilmiah Kesehatan.

Rasyid R.R, A., Riza, S.M., Indah. (2019). Hubungan Pengetahuan dan Sikap Remaja Terhadap Pencegahan HIV/AIDS di SMA PGRI 2 Banjarmasin Tahun 2018. JNA, 1(1), $1-10$.

Sagita, D.D., Hermawan, D. (2020). Kesepian Remaja Pada Masa Pandemi COVID-19. Enlighten, 3(2), 122-130. https://doi.org/10.32505/enlighten.v3 i2. 1892

Sari, D.P., Sholihah, N., Atiqoh. (2020). Hubungan antara Pengetahuan 
Masyarakat dengan Kepatuhan Penggunaan Masker sebagai Upaya Pencegahan Penyakit COVID-19 di Ngronggah. Jurnal Ilmiah Rekam Medis dan Informasi Kesehatan, 10, 52-55.

Satuan Tugas Penanganan COVID-19. (2020). Peta Risiko | Gugus Tugas Percepatan Penanganan COVID-19 [WWW Document]. covid19.go.id. URL https://covid19.go.id/petarisiko (accessed 9.21.20).

Sembiring, E.E., Meo, M.L.N. (2020). Pengetahuan dan Sikap Berhubungan dengan Resiko Tertular Covid-19 pada Masyarakat Sulawesi Utara. Jurnal Keperawatan, 16, 75-82.

Setyawati, I., Utami, K., Ariendha, D.S.R. (2020). Perilaku Pencegahan Penularan Covid-19 Remaja Di Sidoarjo. NersMid: Jurnal Keperawatan dan Kebidanan, 3, 111-120.

Situmeang, S.M.F., Sembiring, T.J. (2019). Efektivitas Hand Sanitizer Dalam Membunuh Kuman Di Tangan. Jurnal AnLabMed, 1, 6.

Suprayitno, E., Rahmawati, S., Ragayasa, A., Pratama, M.Y. (2020). Pengetahuan dan Sikap Masyarakat dalam Pencegahan COVID-19. Jurnal Ilmu Kesehatan, 5, 22-27.

Suwandi, G.R., Malinti, E. (2020). Hubungan Tingkat Pengetahuan Dengan Tingkat Kecemasan Terhadap Covid-19 Pada Remaja Di SMA Advent Balikpapan. MANUJU: Malahayati Nursing Journal, 2, 677-685.

WHO. (2009). Natural ventilation for infection control in health-care settings. Geneva: World Health Organization.

Wiranti, Sriatmi, A., Kusumastuti, W. (2020). Determinan Kepatuhan Masyarakat Kota Depok Terhadap Kebijakan Pembatasan Sosial Berskala Besar Dalam Pencegahan Covid-19. Jurnal Kebijakan Kesehatan Indonesia, 9, 117-124.

World Health Organization. (2020). Coronavirus [WWW Document]. Coronavirus.

URL https://www.who.int/healthtopics/coronavirus\#tab=tab_1

Yanti, B., Wahyudi, E., Wahiduddin, W., Novika, R.G.H., Arina, Y.M.D., Martani, N.S., Nawan, N. (2020). Community Knowledge, Attitudes, and Behavior towards Social Distancing Policy as Prevention Transmission of COVID-19 in Indonesia. JAKI, 8, 4. https://doi.org/10.20473/jaki.v8i2.20 20.4-14

Yanti, N.P.E.D., Nugraha, I.M.A.D.P., Wisnawa, G.A., Agustina, N.P.D., Diantari, N.P.A., (2020). Gambaran Pengetahuan Masyarakat tentang COVID-19 dan Perilaku Masyarakat di Masa Pandemi COVID-19. Jurnal Keperawatan Jiwa, 8. 